\title{
A Study on Application of Enzyme Additives to Improve Drying Speed of Urushi Lacquer ${ }^{1}$
}

\author{
Ji Hyeon $\mathrm{PARK}^{2} \cdot$ Jung Hae $\mathrm{PARK}^{2} \cdot$ Soo Chul KIM(D)
}

\begin{abstract}
Laccase was applied to improve the drying speed of urushi lacquer to confirm a potential use of laccase as an enzyme additive. As a result of applying laccase of lacquer and white-rot fungi, drying times for both Korean and Chinese specimens were reduced. All of the specimens to which laccase was applied were dried(set to touch) within 60 minutes from the start of the drying, and the drying rate was improved as the content ratio of laccase increased. In addition, although there were differences in hardening drying time between Korean and Chinese lacquers, it was confirmed that hardening drying took place even at room with temperature of $20 \pm 2{ }^{\circ} \mathrm{C}$ and humidity of 55-60\%. As a result of lacquer layer analysis of the dried specimens, the drying speed was improved when the content ratio of laccase to urushiol was 5:1, and there were no differences in chromaticity and adhesion, confirmed that the layers were stable. It was observed that the gloss of both Korean and Chinese lacquers were reduced when laccase was applied. However, according to the analysis of FT-IR and Py-GC/MS, the changes in components were not as sufficient to affect the physical properties. Thus, its applicability as an additive was confirmed.
\end{abstract}

Keywords: urushi lacquer, enzyme, additive, drying speed, lacquerware analysis

\section{INTRODUCTION}

Lacquer has been widely used as a paint for wood products since it is durable, waterproof and moisture-proof. Although it is not clear exactly when the lacquer was started to be used in Korea, it seems that lacquer culture has been around since ancient times since various lacquerware artifacts have been excavated from the ruins of Namseong-ri, Asan, Chungnam, Sinchang-dong, Gwangju, Daho-ri, Changwon and Muryeong Royal Tombs, Gongju (Lee, 2010). As the lacquer culture has been succeeded and developed since ancient times, various materials and manufacturing techniques were used. And the lacquerware cultural properties which were produced as such well indicate the life and culture from that era (Kim, 2007).

The conservation of cultural properties relies on the conservation of their prototypes in principle, and the restoration materials shall also be the same with

${ }^{1}$ Date Received December 27, 2019, Date Accepted April 23, 2020

2 Department of Heritage conservation and Restoration, Graduate School of Cultural Heritage, Korea National University of Cultural Heritage, Buyeo 33115, Republic of Korea

${ }^{3}$ Department of Conservation Science, Korea National University of Cultural Heritage, Buyeo 33115, Republic of Korea

$\dagger$ Corresponding author: Soo Chul KIM (e-mail: oldforest@nuch.ac.kr, ORCID: 0000-0002-3508-8386) 
those used for the original properties (Lee, 2017). Thus, a natural material of lacquer shall be used for the conservation of the lacqeurware cultural properties. However, since the ratio of materials in lacquer collected from the lacquer tree varies depending on manufacturing locations, harvesting times, and processing methods (Song and Han, 2001), there are differences in quality and drying patterns of lacquer, and drying conditions are complicated. Therefore, it has a limitation in conserving lacqeurware cultural properties.

Lacquer is a natural material that forms threedimensional polymers via urushiol oxidation, consisting of urushiol, moisture, rubber, nitrogenous materials and enzymes (Do and Lee, 1999). As the main component of lacquer, urushiol gets hardened and dried when contacted by oxygen, forming layers (Park and Ahn, 2018). Since the activation of enzymes occurs only under the presence of moisture, high humidity conditions are needed for drying lacquer (Shin, 2008). In addition, since enzyme is also not activated at a temperature above $50{ }^{\circ} \mathrm{C}$, a lower temperature condition is required. Various materials used for lacquerware such as wood, metal, and leather, could cause secondary damages when exposed to high humidity conditions for hardening and drying lacquer, limiting the accessibility of using lacquer for the conservation.

Therefore, this study aims to apply laccase as an enzyme additive, supplements the differences in composition by region and improves the drying speed in order to enhance the accessibility of using the natural material of lacquer. In addition, it also aims to inves- tigate the stability of additives through the analysis of lacquer layers, so that it could be used in conserving the lacquerware cultural properties.

\section{MATERIALS and METHODS}

\subsection{Materials}

\subsubsection{Lacquer}

Korean and Chinese unrefined lacquers were used to compare the ratio of components of lacquer by region. The unrefined lacquer refers to a lacquer whose impurities were removed without going through a refinement process after collecting lacquer from a part of a lacquer tree by scratching it with a scythe (Son, 2006). Korean unrefined lacquer was manufactured in Wonju, and Chinese unrefined lacquer was purchased from the market.

\subsubsection{Wood specimen}

In this study, specimens for lacquer were produced by using pine trees which are relatively easy to obtain and process. Wooden boards having the dimension of $5.8 \mathrm{~cm} \times 20 \mathrm{~cm} \times 1.2 \mathrm{~cm}$ were cut out, and those without knots or defects were selected and used as specimens.

\subsubsection{Strains and medium}

The strains were cultured and refined by obtained from korean mushroom resource bank(KMRB) for pleurotus ostreatus, coriolus versicolor, and lentinula edodes, among the white-rot fungi that secrete laccase enzyme (Jung, 2019). The strains were inoculated into

Table 1. Composition proportion of lacquer by place of production

\begin{tabular}{ccccc}
\hline Lacquer & Urushiol & Water & Nitrogenated material & Gum and Laccase \\
\hline \hline Korean & $72 \%$ & $20 \%$ & $1 \%$ & $7 \%$ \\
Chinese & $55 \%$ & $16 \%$ & $7 \%$ & $22 \%$ \\
\hline
\end{tabular}


Potato dextrose agar slant, incubated at $22{ }^{\circ} \mathrm{C}$, stored at $4{ }^{\circ} \mathrm{C}$, and subcultured in PDA medium every 4 weeks (Park et al., 1993). For the liquid medium for enzyme refinement, $20 \mathrm{~g}$ of malt extract, $5 \mathrm{~g}$ of yeast extract, $10 \mathrm{~g}$ of dextrose, and $5 \mathrm{~g}$ of peptone at $\mathrm{pH}$ 5.5 per liter were used (Jeong et al., 1992).

\subsubsection{Enzyme refinement}

To apply the laccase as an additive, it was refined in lacquer and white-rot fungi. The lacquer was separated into its main components, urushiol, water, glycoprotein, rubber, and enzyme, using acetone and water in accordance with the lacquer separation method suggested by 'Standardization, Diversification and Mass Production Process Development of Traditional Lacquer' (Han, 2013).

After unrefined lacquers by region were dissolved in acetone and centrifuged, the supernatant separation process was repeated 3 to 4 times. Then only urushiol was refined, and the acetone was evaporated. After urushiol is separated, the remaining acetone powder is dried by a filter paper. The dried acetone powder is then dissolved in distilled water to filter out insoluble nitrogen content. Then, the soluble rubber content and laccase content were separated, concentrated and stored in a refrigerator.

Three types of strains sub-cultured in PDA medium every 4 weeks were inoculated into the liquid medium and shake-cultured in a $25{ }^{\circ} \mathrm{C}$ incubator (Kim et al., 1987). After 7 days of the shake-culturing, it was put

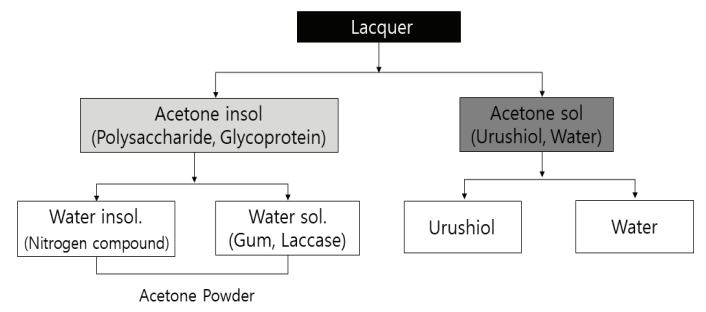

Fig. 1. Process of separating components of lacquer. in the filtrate, from which the mycelium was removed with a filter paper, to put $80 \%$ ammonium sulfate and then it was centrifuged for 20 minutes at $4{ }^{\circ} \mathrm{C}$ and $12,000 \times \mathrm{g}$. The precipitate of the centrifuged filtrate was dissolved in a $0.02 \mathrm{M}$ phosphate buffer solution, dialyzed with the same buffer solution for 24 hours, and vacuum freeze-drying was performed (Won et al., 2004).

\subsubsection{Specimen production}

The proportion of the enzyme to urushiol was adjusted, and specimens were produced by adding laccase of lacquer into the unrefined lacquers by region. At the same time, in order to examine the possibility of applying laccase of white-rot fungi, it was applied using the most suitable content ratio among the results of applying laccase to lacquer (Table 2).

For lacquering, the concentration is adjusted by using volatile terepine oil as a diluent for ease of painting (Hwang, 2018). In order to assimilate the work with the actual working conditions, application

Table 2. List of samples by proportion of Urushiol to Laccase

\begin{tabular}{cccc}
\hline Samples & $\begin{array}{c}\text { Proportion } \\
\text { (Urushiol : Laccase) }\end{array}$ & Samples & Fungi \\
\hline \hline $\mathrm{A}$ & Original & $\mathrm{XP}$ & $\begin{array}{c}\text { Pleurotus } \\
\text { ostreatus }\end{array}$ \\
$\mathrm{B}$ & $5: 1$ & $\mathrm{XC}$ & $\begin{array}{c}\text { Coriolus } \\
\text { versicolor }\end{array}$ \\
$\mathrm{C}$ & $4.5: 1$ & & Lentinula \\
$\mathrm{D}$ & $4: 1$ & $\mathrm{XL}$ & edodes \\
$\mathrm{E}$ & $3.5: 1$ & & - \\
$\mathrm{F}$ & $3: 1$ & - & - \\
$\mathrm{G}$ & $2.5: 1$ & & \\
$\mathrm{H}$ & $2: 1$ & & \\
\hline
\end{tabular}

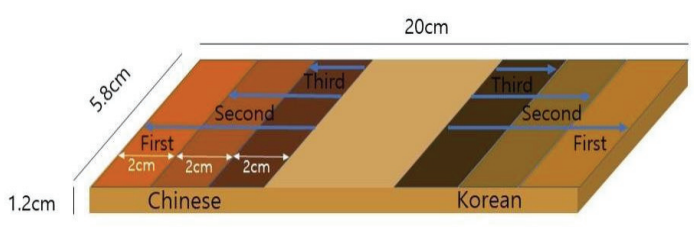

Fig. 2. A process of making samples. 
was done with 10:1 ratio between lacquer specimen and terpene oil. Korean and Chinese lacquer added by laccase of lacquer and white-rot fungi was applied to wood specimens 3 times in the order of initial (Chochil), medium (Jungchil), and last coating (Sangchil) according to region. Then, the samples were put into a drying room and dried (Fig. 2).

\subsection{Methods}

\subsubsection{Drying time}

The lacquer specimens produced by adjusting proportion of laccase to urushiol were dried under conditions with temperature of $25 \pm 1{ }^{\circ} \mathrm{C}$ and humidity of $85-90 \%$ in a drying room. The drying patterns of lacquer specimens by region were observed every $30 \mathrm{mi}-$ nutes with respect to the content ratio of the enzyme to urushiol and number of applications, and the time at which hardening drying of the lacquer completed was measured. In addition, the specimens prepared in the same way were exposed to a room with temperature of $20 \pm 2{ }^{\circ} \mathrm{C}$ and humidity of $55-60 \%$ to confirm the possibility of drying at room temperature condition.

To identify the status of dry condition, set-to touch drying and hardening drying were first confirmed in accordance with 'Test Method 2511 for Drying Time of Application (varnish, lacquer, enamel and water-based paints)' among the 'Test Methods for KS M 5000 Paints and Related Raw Materials', followed by measuring the drying time.

\subsubsection{Chromaticity and gloss}

Chromaticity and gloss were measured 3 times repeatedly on the specimen surface for each condition by using a spectrophotometer (CR-400, KONICA MINOLTA) and a spectrophotometer (A-6800, BYK). The chromaticity measurement values are $L^{*}, a^{*}, b^{*}$ values, and the gloss as a $G$ values.
Based on the $L^{*}, a^{*}$, and $b^{*}$ values of the original lacquer (A), and using Eq. (1), the measured values for each specimen were substituted in $L^{\prime *}, a^{\prime *}$, and $b^{\prime *}$ to obtain the chromaticity difference value $\left(\Delta \mathrm{E}^{*}\right)$ (Hidayat et al., 2017). In general, the chromaticity differences below $\Delta \mathrm{E} 3$ are not recognized, and those below $\Delta \mathrm{E} 6$ are assumed to have the same chromaticity.

$$
\triangle E^{*}=\sqrt{\left(L^{*}-L^{\prime *}\right)^{2}+\left(a^{*}-a^{*}\right)^{2}+\left(b^{*}-b^{*}\right)^{2}}
$$

$$
\begin{aligned}
& \mathrm{L}^{*}: \text { Degree of lightness (white } 100 \sim 0 \text { dark) } \\
& \mathrm{a}^{*}: \text { Degree of redness (red }+50 \sim-50 \text { green) } \\
& \mathrm{b}^{*}: \text { Degree of yellowness (yellow }+50 \sim-50 \text { blue) }
\end{aligned}
$$

\subsubsection{Observation of surface}

In order to examine the drying patterns of the lacquer surface following the enzyme addition, the dried lacquer specimens surface were observed with a portable microscope (Lite plus AM313, DINO). The specimen surface was observed at a $60 \mathrm{x}$ magnification, and the surfaces of the medium layers and last layers among the dried lacquer specimens were photographed.

\subsubsection{Observation of cross section}

From the dried lacquer specimens, sections of the three times coatings were collected to prepare thin slices. After placing the slices on a slide glass, 50\% glycerin aqueous solution was dropped, and the slices were covered with a cover glass to produce microscopic observations. The cross sections of the layers on the preparat was observed by using an optical microscope (Eclipse Lv 100, Nikon, Japan) (Kim et al., 2010).

\subsubsection{Adhesion}

The adhesion of the dried specimens were evaluated by using 'KS M ISO 2409, paint and varnish-paint 
adhesion test method'. Using a scalpel, 6 horizontal lines and 4 vertical lines were cut in a grid pattern on the specimens to make 30 scales with a $5 \mathrm{~mm}$ gap. First, a transparent adhesive tape was attached on the specimen with the grid formed, and peeled off to allow for the calculation of the separated area (Roh and Kim, 2008). The adhesion was evaluated on the twice and three times coated lacquer layers.

\subsubsection{Infrared spectroscopic analysis}

Infrared spectroscopy analysis was carried out to observe the changes in the composition of lacquer by each region following the laccase addition. The infrared spectroscopy analysis was performed by using the Cary620 Microscope (Agilent, USA) FT-IR equipment on the specimens that were prepared by drying only lacquer on a glass plate (Kim, 2016). With the analysis condition set to ATR mode, scanning was performed 32 times repeatedly at the resolution of $4 \mathrm{~cm}^{-1}$ and measurement range of 400 to $4,000 \mathrm{~cm}^{-1}$ (Lee and Kim, 1990).

\subsubsection{Pyrolysis gas chromatography mass spectrometry}

The pyrolysis gas chromatography mass spectrometry was performed to confirm the changes in lacquer composition based on adding the laccase. Using a pyrolysis device (Py-3030D, Frontier Lab, JPN), the dried only lacquer specimen was injected into its inlet without pretreatment and analyzed. $250{ }^{\circ} \mathrm{C}$ was set as the inlet temperature, and $600{ }^{\circ} \mathrm{C}$ as the pyrolytic temperature.

The analysis was performed with a DB-5ms column (Agilent, USA) by using a gas chromatography/mass spectrometer (6890A, Agilent, USA / 5975C, Agilent, USA). The temperature of the oven was set to maintain at $40{ }^{\circ} \mathrm{C}$ for 5 minutes, and to increase at a rate of $20{ }^{\circ} \mathrm{C}$ per minute up to $300{ }^{\circ} \mathrm{C}$, and maintain the temperature for 10 minutes for the analysis. In split mode, helium was used as the gas at the mobile phase with the flow rate of $1.0 \mathrm{~mL} / \mathrm{min}$. The ion source of the mass spectrometer was $\mathrm{EI} 70 \mathrm{eV}$ (Choi and Kim, 2018).

\section{RESULTS and DISCUSSION}

\subsection{Drying time}

In the case of applying laccase of lacquer and whiterot fungi, drying time was shorter than in a case of not applying the laccase to lacquer in both Korean and Chinese specimens. In addition, all the specimens to which laccase was applied were dried (set to touch) within the 60 minutes from the start of the drying, and the drying speed was improved with the increase in the content ratio of laccase (Table 4).

As a result of applying laccase of the lacquer, it was confirmed that the drying rate was improved and no changes in the surface was observed with the naked eyes when the proportion of laccase to urushiol was 5:1. Therefore, the proportion of laccase to urushiol at 5:1 was judged to be the most stable condition. Then, the laccase of the refined white-rot fungi was applied with the same ratio and tested.

When laccase of the white-rot fungi was applied, it was found that drying time of initial coating was reduced only for the Korean specimens, and drying rate of the Chinese specimens were slowed down

Table 3. Hardening drying time of samples applied on laccase of lacquer (room temperature condition)

\begin{tabular}{cccc}
\hline Sample & $\begin{array}{c}\text { Number of } \\
\text { times }\end{array}$ & $\begin{array}{c}\text { Type of } \\
\text { lacquer }\end{array}$ & $\begin{array}{c}\text { Hardening } \\
\text { drying time } \\
(\mathrm{min})\end{array}$ \\
\hline \hline \multirow{2}{*}{ First } & Korean & 240 \\
& Chinese & 180 \\
\cline { 2 - 4 }$(5: 1)$ & \multirow{2}{*}{ Second } & Korean & 360 \\
\cline { 2 - 4 } & \multirow{2}{*}{ Third } & Chinese & 2,160 \\
& & Korean & 180 \\
& & Chinese & 1,440 \\
\hline
\end{tabular}


Table 4. Hardening drying time of samples on the proportion of urushiol and laccase (min)

\begin{tabular}{|c|c|c|c|c|c|}
\hline Samples & $\begin{array}{c}\text { Proportion } \\
\text { (Urushiol : Laccase) } \\
\end{array}$ & Type of lacquer & $\begin{array}{c}\text { First } \\
\text { (Chochil) } \\
\end{array}$ & $\begin{array}{c}\text { Second } \\
\text { (Jungchil) }\end{array}$ & $\begin{array}{c}\text { Third } \\
\text { (Sangchil) }\end{array}$ \\
\hline \multirow{2}{*}{ A } & \multirow{2}{*}{$\begin{array}{l}\text { Original } \\
\text { Lacquer }\end{array}$} & Korean & 240 & 120 & 120 \\
\hline & & Chinese & 300 & 120 & 150 \\
\hline \multirow{2}{*}{$\mathrm{B}$} & \multirow{2}{*}{$5: 1$} & Korean & 120 & 120 & 90 \\
\hline & & Chinese & 210 & 120 & 120 \\
\hline \multirow{2}{*}{$\mathrm{C}$} & \multirow{2}{*}{$4.5: 1$} & Korean & 120 & 120 & 90 \\
\hline & & Chinese & 210 & 120 & 120 \\
\hline \multirow{2}{*}{$\mathrm{D}$} & \multirow{2}{*}{$4: 1$} & Korean & 120 & 120 & 90 \\
\hline & & Chinese & 180 & 120 & 120 \\
\hline \multirow{2}{*}{$\mathrm{E}$} & \multirow{2}{*}{$3.5: 1$} & Korean & 120 & 120 & 90 \\
\hline & & Chinese & 180 & 120 & 120 \\
\hline \multirow{2}{*}{$\mathrm{F}$} & \multirow{2}{*}{$3: 1$} & Korean & 90 & 90 & 90 \\
\hline & & Chinese & 180 & 120 & 120 \\
\hline \multirow{2}{*}{ G } & \multirow{2}{*}{$2.5: 1$} & Korean & 90 & 90 & 90 \\
\hline & & Chinese & 180 & 120 & 120 \\
\hline \multirow{2}{*}{$\mathrm{H}$} & \multirow{2}{*}{$2: 1$} & Korean & 90 & 90 & 90 \\
\hline & & Chinese & 120 & 120 & 120 \\
\hline \multirow{2}{*}{$\mathrm{XP}$} & \multirow{2}{*}{ Pleurotus ostreatus } & Korean & 150 & 120 & 90 \\
\hline & & Chinese & 360 & 150 & 120 \\
\hline \multirow{2}{*}{$\mathrm{XC}$} & \multirow{2}{*}{ Coriolus versicolor } & Korean & 150 & 90 & 90 \\
\hline & & Chinese & 360 & 120 & 120 \\
\hline \multirow{2}{*}{$\mathrm{XL}$} & \multirow{2}{*}{ Lentinula edodes } & Korean & 150 & 90 & 90 \\
\hline & & Chinese & 360 & 120 & 120 \\
\hline
\end{tabular}

than that of the Original lacquer. In the case of medium and last coatings, drying speed was improved in a pattern similar to that of the specimen with the laccase of the lacquer applied regardless of the regions.

The results of the room temperature condition drying experiment showed that although there was a difference in hardening drying time between the Korean and Chinese spceimens, it was confirmed that hardening drying performed even in the room with temperature of $20 \pm 2{ }^{\circ} \mathrm{C}$ and humidity of $55-60 \%$ (Table $3)$. In contrast to original lacquer not dried in room temperature condition, when laccase added as an additive, drying rate not only improved but also expected to improve the drying conditions requiring high humidity.

\subsection{Chromaticity and gloss}

Based on the chromaticity of original specimen A, the $\Delta \mathrm{E}^{*}$ values of specimens with second coatings of laccase of the lacquer and those values of the specimens with third coatings were both less than 3 , which were not significant enough to be recognized as a difference in color (Table 5). Since the largest $\Delta \mathrm{E}^{*}$ value of the XL specimen was 6 , which was within the range of values that are regarded as no changes in color (Table 6), the changes in color of lacquer due to the laccase addition were not as significant.

In the case of second coatings, the gloss of all the specimens with the laccase of the lacquer and whiterot fungi applied was lower than that of the original lacquer. In addition, it was revealed that the higher 
Table 5. Color differences $\left(\Delta \mathrm{E}^{*}\right)$ and degree of gloss $(\mathrm{G})$ after drying of sample applied to the laccase of lacquer (Third)

\begin{tabular}{|c|c|c|c|c|c|c|c|c|}
\hline Sample & Korean & & $\Delta \mathrm{E}^{*}$ & $\mathrm{G}$ & Chinese & & $\Delta \mathrm{E}^{*}$ & $G$ \\
\hline \multirow{3}{*}{ A } & $\mathrm{L}^{*}$ & 27.92 & & & $\mathrm{~L}^{*}$ & 26.22 & & \\
\hline & $a^{*}$ & -0.22 & - & 28.10 & $a^{*}$ & -0.20 & - & 29.67 \\
\hline & $\mathrm{b}^{*}$ & -0.07 & & & $b^{*}$ & -0.49 & & \\
\hline \multirow{3}{*}{ B } & $\mathrm{L}^{*}$ & 27.55 & & & $\mathrm{~L}^{*}$ & 26.44 & & \\
\hline & $a^{*}$ & 0.43 & 0.85 & 8.93 & $\mathrm{a}^{*}$ & 1.37 & 1.60 & 37.63 \\
\hline & $\mathrm{b}^{*}$ & -0.47 & & & $b^{*}$ & -0.26 & & \\
\hline \multirow{3}{*}{$\mathrm{C}$} & $\mathrm{L}^{*}$ & 27.74 & & & $\mathrm{~L}^{*}$ & 26.32 & & \\
\hline & $a^{*}$ & 0.07 & 0.62 & 7.86 & $a^{*}$ & -0.06 & 0.33 & 34.70 \\
\hline & $\mathrm{b}^{*}$ & -0.59 & & & $b^{*}$ & -0.77 & & \\
\hline \multirow{3}{*}{$\mathrm{D}$} & $\mathrm{L}^{*}$ & 28.07 & & & $\mathrm{~L}^{*}$ & 26.19 & & \\
\hline & $a^{*}$ & 0.89 & 1.19 & 7.60 & $a^{*}$ & 0.01 & 0.31 & 37.43 \\
\hline & $b^{*}$ & -0.47 & & & $b^{*}$ & -0.72 & & \\
\hline \multirow{3}{*}{$\mathrm{E}$} & $\mathrm{L}^{*}$ & 27.33 & & & $\mathrm{~L}^{*}$ & 25.72 & & \\
\hline & $a^{*}$ & 0.60 & 1.05 & 9.23 & $a^{*}$ & -0.03 & 0.58 & 33.83 \\
\hline & $\mathrm{b}^{*}$ & -0.34 & & & $b^{*}$ & -0.73 & & \\
\hline \multirow{3}{*}{$\mathrm{F}$} & $\mathrm{L}^{*}$ & 28.08 & & & $\mathrm{~L}^{*}$ & 25.59 & & \\
\hline & $a^{*}$ & 0.10 & 0.36 & 14.50 & $a^{*}$ & 0.05 & 0.72 & 19.76 \\
\hline & $\mathrm{b}^{*}$ & -0.01 & & & $b^{*}$ & -0.72 & & \\
\hline \multirow{3}{*}{ G } & $\mathrm{L}^{*}$ & 27.76 & & & $\mathrm{~L}^{*}$ & 25.28 & & \\
\hline & $a^{*}$ & 1.05 & 1.60 & 2.93 & $a^{*}$ & 0.24 & 1.04 & 18.46 \\
\hline & $b^{*}$ & 0.89 & & & $b^{*}$ & -0.57 & & \\
\hline \multirow{3}{*}{$\mathrm{H}$} & $\mathrm{L}^{*}$ & 27.04 & & & $\mathrm{~L}^{*}$ & 25.43 & & \\
\hline & $a^{*}$ & 0.36 & 1.15 & 11.60 & $a^{*}$ & 0.18 & 0.92 & 17.26 \\
\hline & $\mathrm{b}^{*}$ & 0.39 & & & $b^{*}$ & -0.76 & & \\
\hline
\end{tabular}

content ratio of laccase results in the smaller gloss. It was assumed that as the drying rate of lacquer improves, a rapid oxidation reaction occurs to have an interference causing the light to scatter on the lacquer surface. 
Table 6. Color differences $\left(\Delta \mathrm{E}^{*}\right)$ and degree of gloss $(\mathrm{G})$ after drying of sample applied to the laccase of white-rot fungi (Third)

\begin{tabular}{|c|c|c|c|c|c|c|c|c|}
\hline Sample & Korean & & $\Delta \mathrm{E}^{*}$ & $\mathrm{G}$ & Chinese & & $\Delta \mathrm{E}^{*}$ & $\mathrm{G}$ \\
\hline \multirow{3}{*}{ XP } & $\mathrm{L}^{*}$ & 27.81 & & & $\mathrm{~L}^{*}$ & 26.25 & & \\
\hline & $a^{*}$ & 1.43 & 2.02 & 15.16 & $a^{*}$ & -0.09 & 0.33 & 17.23 \\
\hline & $\mathrm{b}^{*}$ & 1.09 & & & $\mathrm{~b}^{*}$ & -0.18 & & \\
\hline \multirow{3}{*}{$\mathrm{XC}$} & $\mathrm{L}^{*}$ & 27.16 & & & $\mathrm{~L}^{*}$ & 26.55 & & \\
\hline & $a^{*}$ & 1.37 & 2.07 & 14.80 & $a^{*}$ & -0.08 & 0.35 & 20.80 \\
\hline & $b^{*}$ & 1.01 & & & $b^{*}$ & -0.44 & & \\
\hline \multirow{3}{*}{ XL } & $\mathrm{L}^{*}$ & 28.39 & & & $\mathrm{~L}^{*}$ & 26.20 & & \\
\hline & $a^{*}$ & 2.79 & 3.88 & 21.49 & $a^{*}$ & -0.18 & 0.11 & 13.70 \\
\hline & $b^{*}$ & 2.33 & & & $\mathrm{~b}^{*}$ & -0.38 & & \\
\hline
\end{tabular}

\subsection{Observation of surface}

Observation of the surface of the dried lacquer specimen showed that lacquer was more evenly applied, and as the number of applications increased, the solid color of the lacquer was observed instead of the wood color of the specimen.

As the laccase content ratio increased in both Korean and Chinese lacquer specimens with laccase of lacquer applied, fine cracks were observed on surfaces just as in $\mathrm{G}$ and $\mathrm{H}$ (Table 7). As the number of applications was increased, wrinkles such as rumpling on the surface of the lacquer were observed on the specimens with laccase of white-rot fungi applied (Table 8).

The thickness of lacquer layers was $30-40 \mu \mathrm{m}$ for each layer, which suggests that relatively similar amounts were applied for each application. However, as the content ratio of laccase increased, It is estimated that when the laccase of white-rot fungi was added in the process of hardening last layer, drying time got relatively longer than when laccase of the lacquer was added, and resulting in fine cracks or wrinkles. A further study is needed on this aspect.

\subsection{Observation of cross section}

In case of initial coating, patterns of lacquer smudged into the wood and layers being formed on top were confirmed in both specimens with laccase of lacquer and white-rot fungi. The observations revealed that the thickness of the layers in the Korean lacquer at approximately $25 \mu \mathrm{m}$ to $45 \mu \mathrm{m}$ for first layer, approximately $20 \mu \mathrm{m}$ to $40 \mu \mathrm{m}$ of second layer, and approximately $25 \mu \mathrm{m}$ to $45 \mu \mathrm{m}$ of third layer. Considering that the layers were achieved in conforming to the number of applications, it could be assumed that hardening drying was formed in all the specimens with laccase applied.

However, as the content ratio of laccase to urushiol increased, fine cracks were observed on the layers of cross section, as can be seen in Korean and Chinese $\mathrm{E} \sim \mathrm{H}$ (Table 9). It is presumed that as drying speed is rapidly increased, the layer-forming process is affected by the difference in shrinkage rate on the lacquer in initial drying stage. 
Table 7. Photomicrographs dried sample of surface (laccase of lacquer)

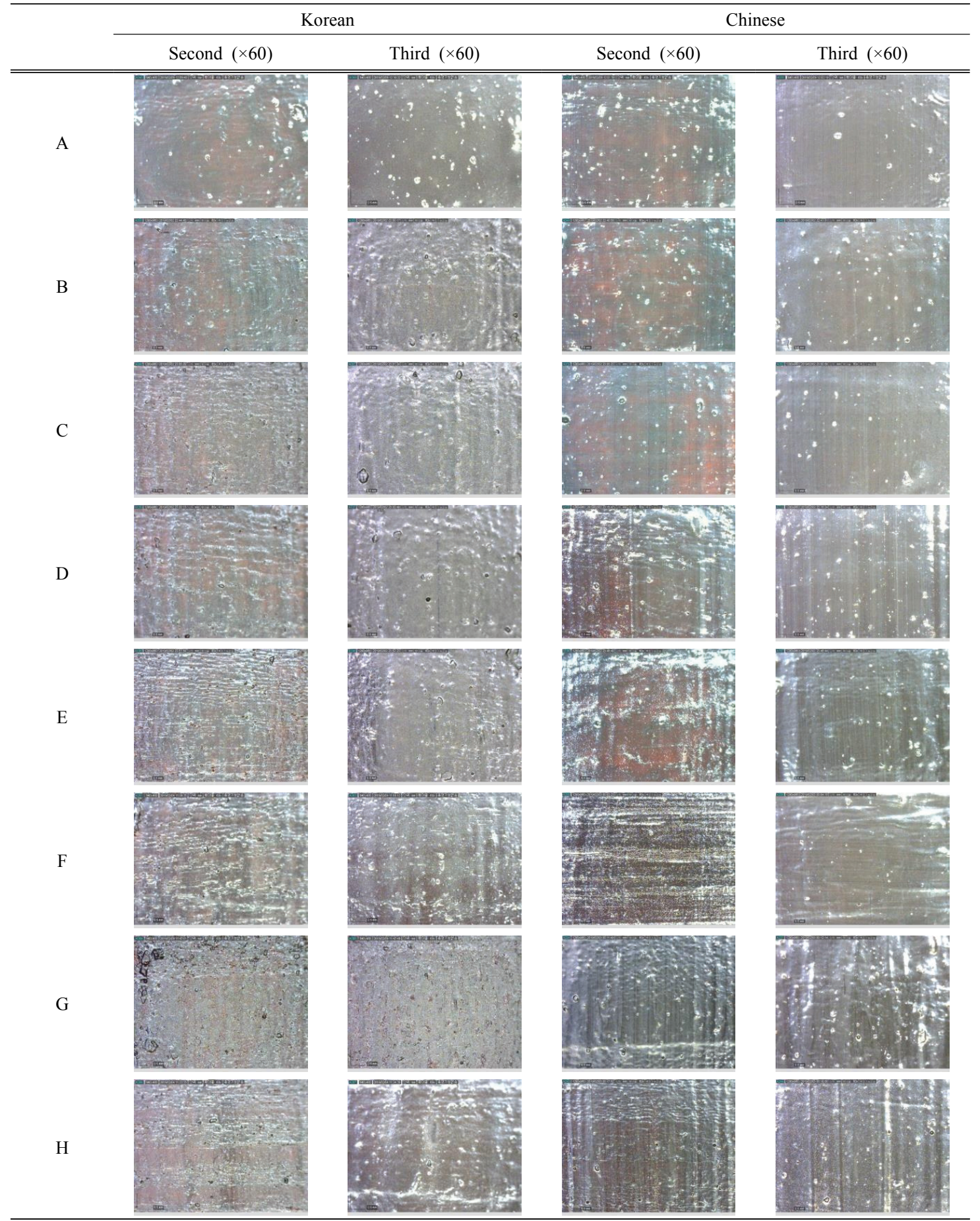


A Study on Application of Enzyme Additives to Improve Drying Speed of Urushi Lacquer

Table 8. Photomicrographs dried sample of surface (laccase of white-rot fungi)

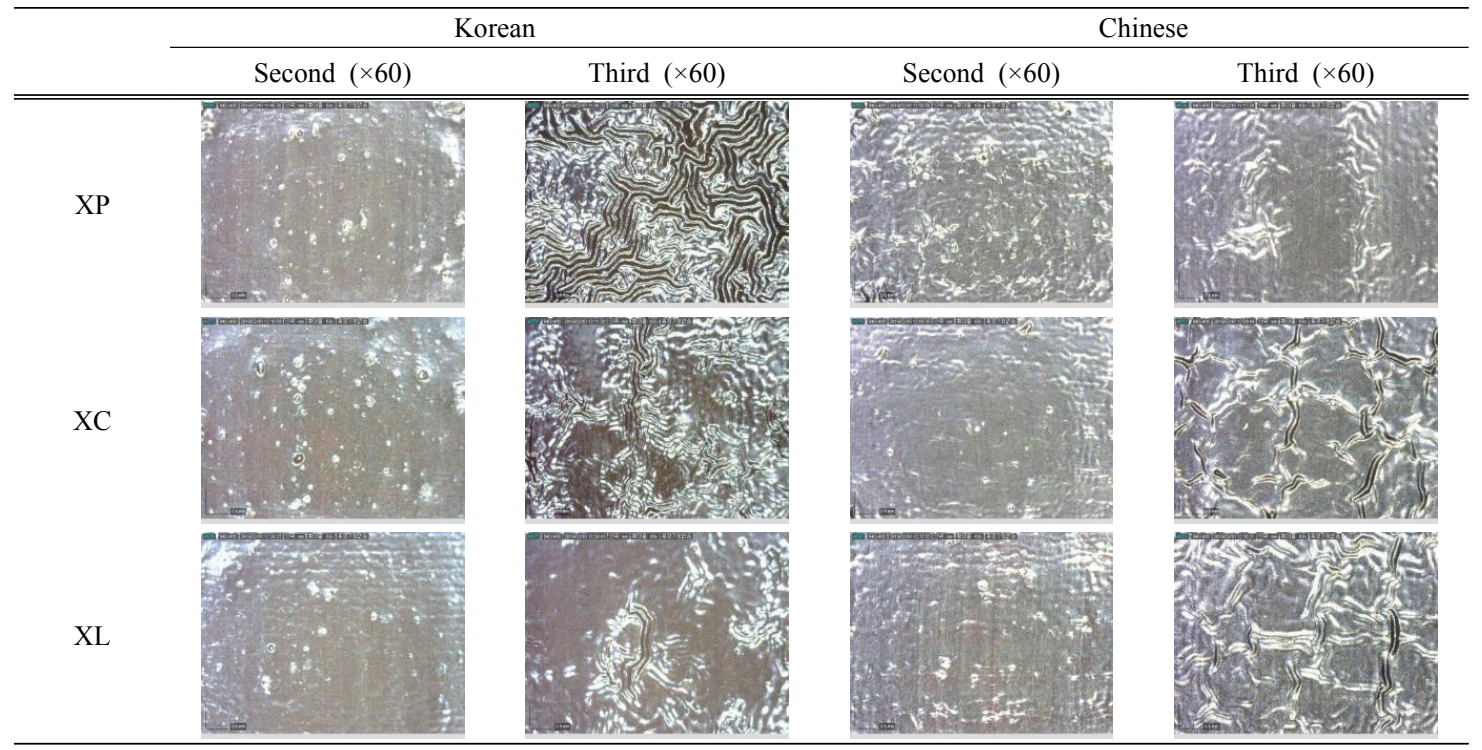

Table 9. Photomicrographs of cross section of film samples coated with laccase of lacquer

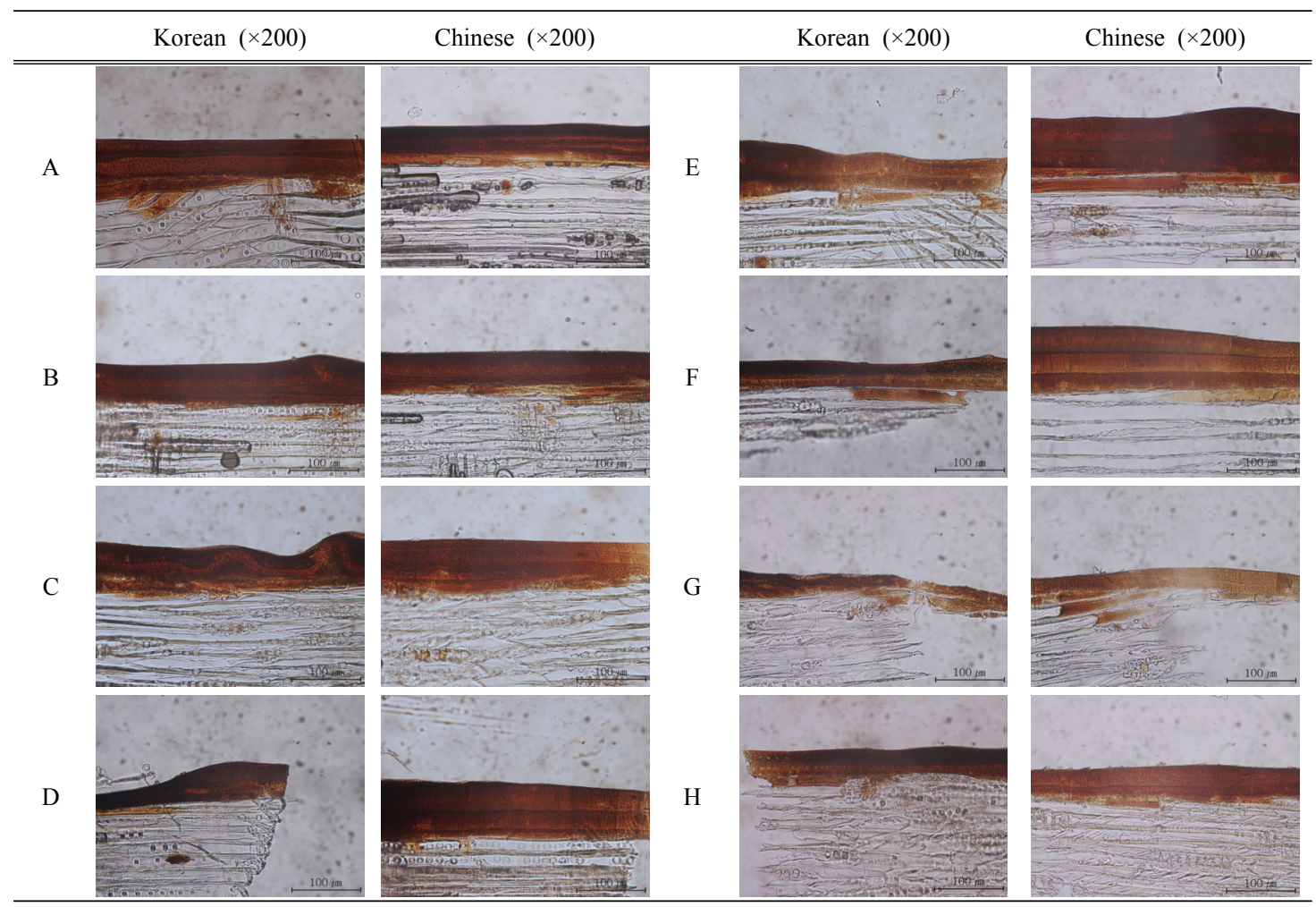


Table 10. Photographs before and after adhesion test

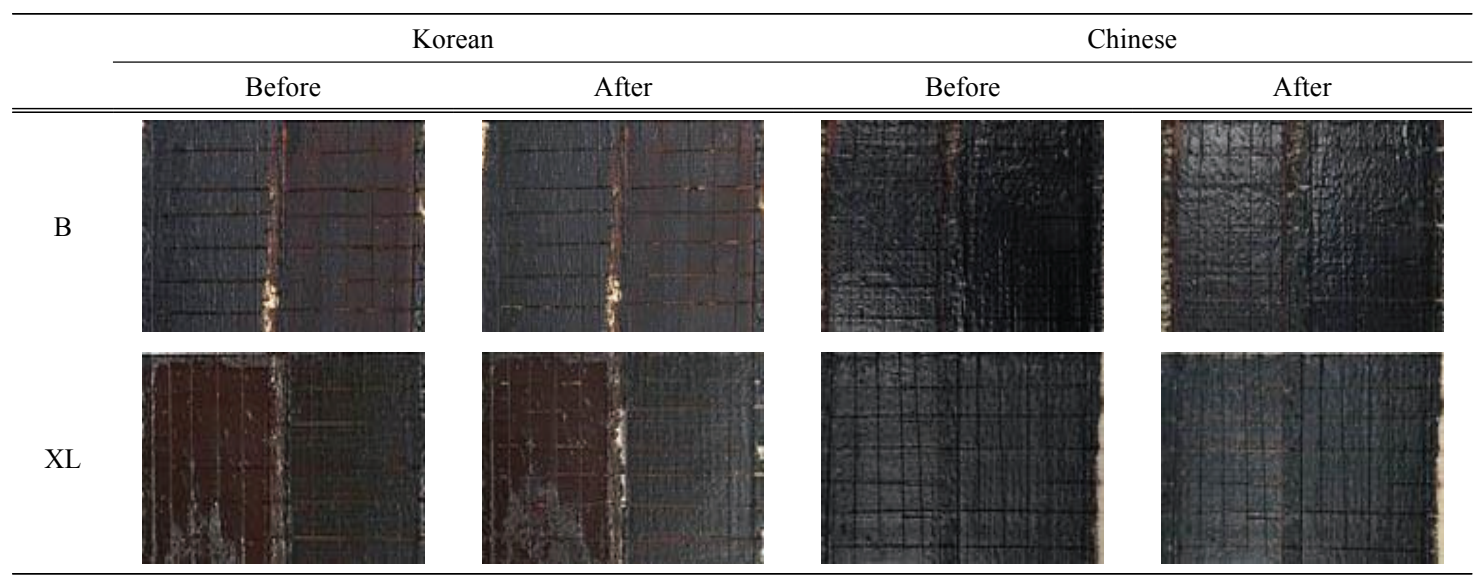

\subsection{Adhesion}

Both specimens with laccase of lacquer and laccase of white-rot fungi applied were confirmed to have peeling off rates of less than $0.5 \%$, since all the surfaces were adhered except for the fine peeling by the scalpel (Table 10). In addition, since the changes in adhesion of lacquer based on the laccase content ratio were not observed, all adhesions of specimens were determined to be stable after hardening drying of the specimens.

\subsection{Infrared spectroscopy}

The similar peaks of spectra had been observed from both Korean and Chinese lacquers, and specific peaks found on original lacquers were observed in the FT-IR spectra of all specimens (Park et al., 2017; Yeon et al., 2019).

As a result of analyzing the magnified fingerprint region of $1,500 \mathrm{~cm}^{-1}$ or less, there was a difference in absorbance observed in the 1,270 to $1,190 \mathrm{~cm}^{-1}$ region where a $\mathrm{C}-\mathrm{O}$ stretching vibration peak appeared depending on the ratio of laccase addition (Fig. 3). When the laccase of white-rot fungi was applied at proportion of $5: 1$, there was a difference in absorbance observed in the same region for both Korean and Chinese spectra, and little difference between lacquers by region (Fig. 4).

This difference seems to be emerged by the structural changes taking place in alcohol or phenol corresponding to this region as the degree of oxidation reaction changed due to the amount of laccase added. Although there were differences in intensity of the the FT-IR spectrum peaks but the peaks did not disappear, so it is consider that it doesn't have a significant effect on physical properties.

\subsection{Pyrolysis gas chromatography mass spectrometry}

In Korean specimens, Benzene-based compounds such as Styrene, Benzene, Propyl-, Benzealdehyde, Benzene, and butyl-, and Phenol-based compounds such as Phenol and 2-propyl- were observed. These components appear when urushiol, the main component of original lacquer, was hardened by an oxidation reaction, and biphenyl-type dimers generated during drying were also identified. In addition, undecane, dodecane, etc. coming from the alkyl chain 


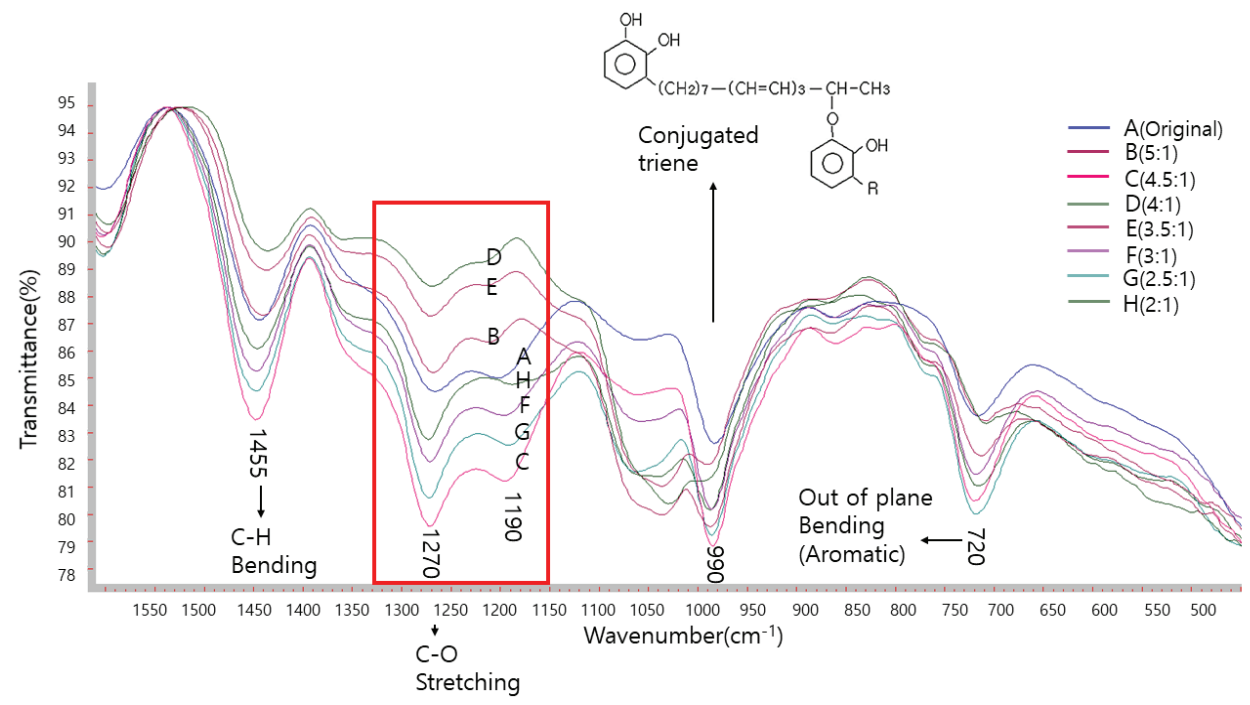

Fig. 3. Total FT-IR spectrum of Korean samples in fingerprint area (laccase of lacquer).

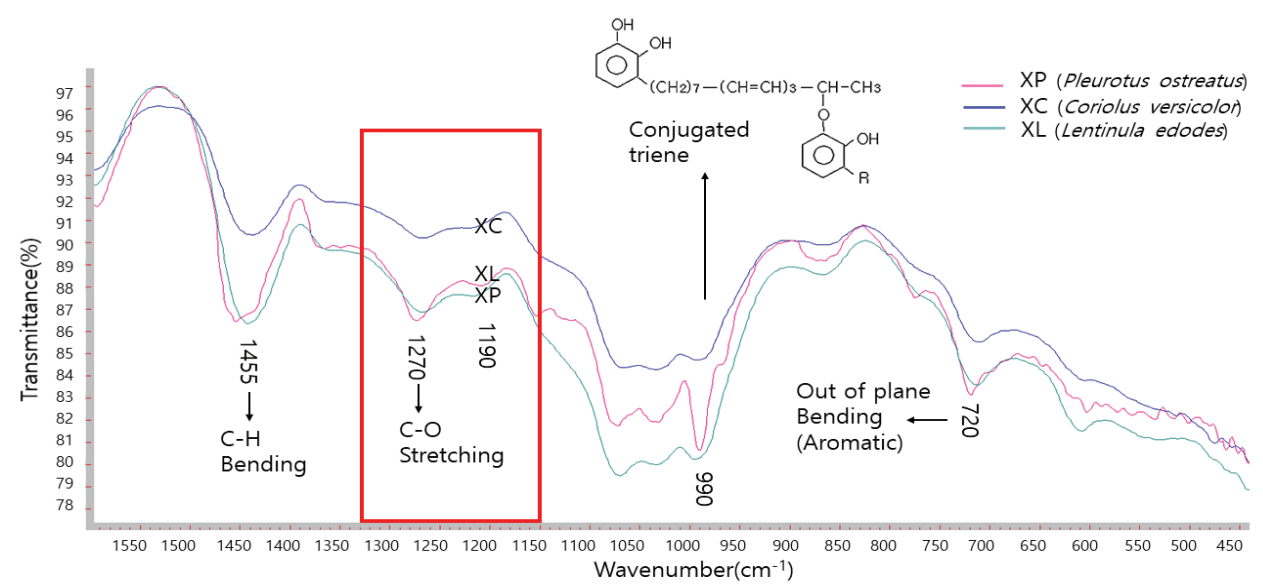

Fig. 4. Total FT-IR spectrum of Chinese sample in fingerprint area (laccase of white-rot fungi).

were detected.

In Chinese specimens, benzene-based compounds such as ethylbenzene, benzene, 1,3-dimethyl-, benzene, propyl-, benzene, 1-methyl-4-propyl, and Phenolbased compounds such as phenol, 2-methyl-, phenol, 4-ethyl- were observed. In addition, components such as decane, undecane, dodecane, tetradecane, and pen- tadecane coming from the alkyl chain were also detected.

The components detected in the lacquer specimen following the laccase addition were mainly those that are detected in the process in which the main component urushiol is oxidized by the hardening and drying process followed by the laccase activation. No differ- 
ences were observed between lacquers by each region. In addition, it is considered that even if laccase is added with 5:1 proportion of laccase to urushiol, no changes occur to the extent that it affects the properties of lacquer while acting as a catalyst for the oxidation reaction of urushiol.

\section{CONCLUSION}

In this study, laccases of lacquer and white-rot fungi were applied to confirm the possibility of its usage as an enzyme additive for improve the drying speed of lacquer. When laccase was applied to both Korean and Chinese lacquers, the drying time of the specimen with laccase applied was shorter than that of the specimen without laccase addition. Also all the specimens with the laccase applied were dried(set to touch) in less than 60 minutes from the start of the drying, and drying speed was improved with increase in the laccase content ratio.

In addition, although there were differences in hardening drying time between Korean and Chinese lacquers, it was confirmed that hardening drying was achieved even at room with temperature of 20 $\pm 2{ }^{\circ} \mathrm{C}$ and humidity of $55-60 \%$. In contrast to original lacquer not dried in room temperature condition, when laccase added as an additive, drying rate not only improved but also expected to improve the drying conditions requiring high humidity.

As a result of lacquer layer analysis of the dried specimens, it was confirmed that the drying speed was improved when the content ratio of laccase to urushiol was 5:1, with no difference in chromaticity and adhesion, suggesting that the layers were stable. It was observed that gloss of both Korean and Chinese lacquers reduced when the lacquer was applied. However, according to the results of FT-IR and Py-GC/MS analysis, the changes in components were not as sufficient to affect the physical properties, suggesting that it can be applied as an additive. Thus, the results of this study suggest that the accessibility of laccase as an additive was confirmed and using lacquer for the conservation of lacquerware cultural properties could be increased, and an authentic conservation could be achieved.

\section{ACKNOWLEDGMENT}

This study was conducted with the support of the 2018 Korea National University of Cultural Heritage Academic Research Support Project.

\section{REFERENCES}

Choi, J.W., Kim, S.C. 2018. Analysis of lacquer and CNSL using infrared spectrometer and pyrolysisGC/MS. Journal of the Korean Wood Science and Technology 46(1): 1-9.

Do, C.H., Lee, T.Y. 1999. Lacquer coatings on the koryo buddhist canon printing wood blocks. Journal of Conservation Science 8(1): 33-39.

Han, J.S. 2014. Diversification and mass production of traditional lacquer. Ministry of Culture, Sports and Tourism Standardization pp.3-11.

Hidayat, W., Qi, Yue., Jang, J.H., Park, B.H., Banuwa, I.S., Febrianto, F., Kim, N.H. 2017. Color change and consumer preferences towards color of heattreated Korean white pine and royal paulownia woods. Journal of the Korean Wood Science and Technology 45(2): 213-222.

Hwang, I.S., Park, J.H., Kim, S.C. 2018. A study on the optical characteristics according to the lacquer drying conditions for the conservation of lacquerwares. Journal of the Korean Wood Science and Technology 46(5): 610-621.

Jeong, I.B., Yoon, H.D., Maeng, J.S., Kang, S.W., Ha, Y.C., Jeong, G.J., Choi, H.T., Kim, J.H. 1992. Characteristics of lacase secreted by Lentinus 
edodes. The Korean Journal of Microbiology 30(4): 252-259.

Jung, H.C. 2019. Enhancement of laccase production from wood-rotting fungus by co-culture with trichoderma longibrachiatum. Journal of the Korean Wood Science and Technology 47(2): 210-220.

Kim, K.J., Shin, K.S., Maeng, J.S., Kang, S.O., Hah, Y.C., Hong, S.W. 1987. Characterization of laccase from Pleurotus ostreatus. The Korean Journal of Microbiology 25(2): 148-156.

Kim, S.C. 2007. Analysis and conservation of lacquer wares from archaeological sites in Korea. Doctoral thesis, Chungbuk National University, Cheongju.

Kim, S.C., Lee, G.H., Kang, H.T., Shin, S.P., Han, M.S. 2010. Lacquer manufacturing method for the wooden coffins of king muryeong's tomb based on the scientific analysis. Journal of Conservation Science 26(3): 247-258.

Kim, J.E. 2016. A study of adhesion characteristics and manufacturing techniques for lacquer with additives. Master thesis, Graduate School of Cultural Heritage, Korea National University of Cultural Heritage, Buyeo.

Lee, P.W., Kim, H.J. 1990. Characteristics of hardening behavior of Korean Rhus Lacquer by F.T.-I.R. Journal of the Korean Wood Science and Technology $18(1)$ : 10-14.

Lee, S.J. 2017. Conservation Ethics, Graphic Korea, pp.61-77, Seoul.

Lee, Y.H. 2010. A study of the techniques of the ancient korean lacquer wares. Master thesis, Kongju National University, Gongju.

Park, S.J., Lee, J.Y., Cho, N.S., Cho, B.M. 1993. Wood science experiment book, Gwangil Cultural Company, pp.623-653, Seoul.
Park, S.Y., Kim, J.C., Kim, J.H., Yang, S.Y., Kwon, O.K., Yeo, H.M., Cho, K.C., Choi, I.G. 2017. Possibility of wood classification in Korean softwood species using near-infrared spectroscopy based on their chemical compositions. Journal of the Korean Wood Science and Technology 45(2): 202-212.

Park, J.S., Ahn, S.A. 2018. Analysis of dried Asian lacquer by pyrolysis/GC/MS. Analytical Science and Technology 31(2): 78-87.

Roh, J.K., Kim,Y.G. 2008. Grade classification of urushi lacquer( II ) grade classification of urushi lacquer by scientific methods. Journal of the Korea Furniture Society 19(5): 307-318.

Son, D.H. 2006. Traditional lacquer craft. Korea Cultural Properties Protection Foundation, pp.8-54.

Song, H.K., Han, C.H. 2001. Study on refining technique of raw lacquer (2): Refining and mechanical properties of refined lacquer according as mixing rate of components. Journal of the Korean Wood Science and Technology 29(1): 43-51.

Shin, S.P. 2008. The evaluation of conservation characteristics on lacquer coats by the reproduction experiment. Master thesis, Kongju National University, Gongju.

Won, C.H., Lee, S.Y., Baek, Y.J. 2004. Degradation of PAHs using Laccase from Trametes sp. Journal of Environmental Science and Technology 5(1): 43-48.

Yeon, S.H., Park, S.Y., Kim, J.H., Kim, J.C., Yang, S.Y., Yeo, H.M., Kwon, O.K., Choi, I.G. 2019. Effect of organic solvent extractives on Korean softwoods classification using near-infrared spectroscopy. Journal of the Korean Wood Science and Technology 47(4): 509-518. 


\title{
APPENDIX
}

\author{
(Korean Version)
}

\section{옻칠의 건조속도 향상을 위한 효소첨가제 적용 연구}

초록 : 옻칠의 건조속도를 향상시키기 위해 Laccase를 적용하여 효소첨가제로써의 가능성을 확인하고자 하였다. 옻칠의 Laccase와 부후균의 Laccase를 적용한 경우 국내산과 중국산 모두 건조시간이 단축되었다. Laccase를 적용한 시험편 모두 건조시작 60 분 안에 지촉건조가 이루어졌으며, Laccase의 함량비율이 높아질수록 건조속도가 향상되었다. 또한 국내산 옻칠과 중국산 옻칠의 경화건조시간의 차이는 있지만 온도 $20 \pm 2{ }^{\circ} \mathrm{C}$, 습도 $55-60 \%$ 의 상온에서도 경화건조가 이루어지는 것이 확인되었다. 건조된 시험편의 도막분석 결과, 우루시올 대비 Laccase 함량비율이 5:1일 때 건조속도가 향상되었으며, 색차와 밀착력의 차이가 없고 도막이 안정적임을 확인하였다. Laccase를 적용한 경우 국내산과 중국산 옻칠의 광택도가 모두 감소되는 양상이 관찰되었으나 이외 FT-IR과 Py-GC/MS의 분석결과 물성에 영향을 미치는 정도의 성분변화는 나타나지 않아 첨가제로써 의 적용 가능성을 확인하였다.

\section{1. 서 론}

옻칠은 예부터 내구성이 좋고 방수성과 방습성을 가지고 있어 목제품의 도료로 널리 사용되어 왔다. 우리나라에서 옻이 사용되기 시작한 시기는 정확하지 않으나 충남 아산 남성리 유적, 광주 신창동 유적, 창원 다호리 유적, 공주 무령왕릉 유적 등에서 다양한 칠기문화재들이 출토된 것으로 보아 칠기문화는 고대부터 이어져 왔음을 짐작할 수 있다(Lee, 2010). 칠기문화가 고대부터 계승되고 발전함에 따라 다양한 재료와 제작기법이 사용되었으며 이렇게 제작된 칠기문화재들은 당대의 생활상과 문화상을 잘 나타내고 있다(Kim, 2007).

문화재의 보존은 원형보존을 원칙으로 하며, 복원재료 역시 문화재에 사용된 것과 동일한 재료를 사용하여야 한다(Lee, 2017). 따라서 칠기문화재 보존을 위해서는 천연재료인 옻칠이 사용되어야 한다. 그러나 옻나무에서 채취한 옻칠은 생산지, 채취시기, 가공방식에 따라 성분비율이 다르기(Song and Han, 2001) 때문에 옻의 품질과 건조양상에 차이가 나타나고 건조조건 을 까다롭게 하여 문화재 보존처리의 적용에 한계를 가진다.

옻칠은 우루시올 산화반응에 의해 3 차원 구조의 고분자를 형성하는 천연물질로서 크게 우루시올, 수분, 고무질, 함질소물과 효소로 구성된다(Do and Lee, 1999). 옻칠의 주성분인 우루시올은 산소와 접촉하면 Laccase의 산화반응에 의해 경화되면서 건조되고 도막이 형성된다(Park and Ahn, 2018). Laccase 효소는 수분의 존재 하에서만 활성이 일어나기 때문에 옻칠이 건조되기 위해서는 높은 습도조건이 필요하다(Shin, 2008). 또한 효소는 $50{ }^{\circ} \mathrm{C}$ 이상의 높은 온도에서도 활성하지 않기 때문에 이보다 낮은 온도조건이 필요하다. 칠기문화재의 소지가 되는 목재, 금속, 가죽 등의 다양한 재료들은 옻칠의 경화 및 건조가 이루어지기 위한 높은 습도조건에 노출되면 2차적인 손상을 일으킬 수 있어 보존처리 시 옻칠 사용의 접근성을 제한시킨다.

따라서 본 연구에서는 Laccase를 효소첨가제로 적용하여 산지별 조성분의 차이를 보완하고 건조속도를 향상시킴으로써 천연재료인 옻칠 사용의 접근성을 높이고자 한다. 또한 첨가제를 적용한 옻칠도막의 분석을 통해 첨가제의 안정성을 확인하여 칠기문화재 보존에 활용되고자 한다.

\section{2. 재료 및 방법}

\section{1. 연구재료}

\subsection{1. 생칠}

산지별 옻칠의 조성성분 비율울 비교하기 위해 국내산과 중국산 생칠을 사용하였다. 생칠은 옻나무에서 긁기낫으로 흠을 내어 채취한 옻액을 불술문만 걸러 정제과정을 행하지 않은 칠을 말한다(Son, 2006). 국내산 생칠은 원주산 옻칠을 사용하였고 중국산 생칠은 시중에 유통되는 옻칠(평화자개)을 구입하여 사용하였다. 


\subsection{2. 목재 시편}

본 연구에서는 비교적 가공이 용이하고 주변에서 구하기 쉬운 소나무를 사용하여 옻칠을 위한 시편을 제작하였다. 시편의 크기는 가로 $5.8 \mathrm{~cm} \times$ 세로 $20 \mathrm{~cm} \times$ 두께 $1.2 \mathrm{~cm}$ 의 정목판재로 제작하였으며, 옹이나 결점이 없는 시편을 선별하여 사용하였다.

\subsection{3. 균주 및 배지}

균주는 Laccase효소가 분비되는 백색부후균류 중 Pleurotus ostreatus, Coriolus versicolor, Lentinula edodes를 버섯소재은행 에서 분양받아 배양 및 정제하였다(Jung, 2019). 분양받은 균주는 Potato dextrose agar slant에 접종하여 $22{ }^{\circ} \mathrm{C}$ 에서 배양한 후 $4{ }^{\circ} \mathrm{C}$ 에 보관하였으며, 4주 간격으로 PDA배지에서 계대배양하였다(Park et al., 1993). 효소정제를 위한 액체배지는 Liter당: malt extract $20 \mathrm{~g}$, yeast extract $5 \mathrm{~g}$ dextrose $10 \mathrm{~g}$, peptone $5 \mathrm{~g}$ 을 pH 5.5로 조절하여 사용하였다(Jeong et al., 1992).

\subsection{4. 효소 정제}

Laccase 효소를 첨가제로 적용하기 위해 옻칠과 백색부후균에서 Laccase효소를 정제하였다. 옻칠은 아세톤과 물을 이용하여 주요성분인 우루시올, 수분, 당단백, 고무질, 효소를 분리하였으며, ‘전통옻칠의 규격화, 다양화 및 대량 생산공정 개발’에서 제시한 옻칠의 분리방법을 사용하였다(Han, 2013).

아세톤에 산지별 생칠을 용해시켜 원심분리한 후 상등액을 분리하는 과정을 3 4회 반복한 후 아세톤을 증발시켜 우루시올만 정제하였다. 우루시올이 분리되고 남은 아세톤파우더는 필터페이퍼로 남아있는 아세톤을 건조시킨다. 건조된 아세톤파우더를 증류수에 녹여 물에 녹지 않는 질소함유물을 걸러내고 물에 녹는 고무질과 Laccase 성분을 분리하고 농축한 후 냉장 보관하였다.

백색부후균은 $\mathrm{PDA}$ 배지에 4주 간격으로 계대배양한 세 종류의 균주를 액체배지에 접종하여 $25^{\circ} \mathrm{C}$ 배양기에 진탕배양하였다 (Kim et al., 1987). 진탕배양 7일 후 여과지로 균사체를 제거한 여과액에 황산암모늄을 $80 \%$ 되게 하여 $4{ }^{\circ} \mathrm{C}, 12,000 \times \mathrm{g}$ 에서 20 분 동안 원심분리하였다. 원심분리에 의한 여과액의 침전물은 $0.02 \mathrm{M}$ 의 인산완충용액에 녹인 후 동일한 완충용액으로 24 시간 동안 투석시켜 진공 동결 건조하였다(Won et al., 2004).

\subsection{5. 시편 제작}

우루시올 대비 효소의 함량비율을 조정하였으며, 정제된 옻칠의 Laccase를 산지별 옻칠에 첨가하여 시편을 제작하였다. 이와 함께 부후균의 Laccase 적용 가능성을 검토하고자 옻칠의 Laccase를 적용한 결과 중 가장 적합한 함량비율을 확인하여 부후균의 Laccase를 적용하였다(Table 2).

옻칠은 칠작업의 용이성을 위해 휘발성이 높은 테레핀유를 희석제로 사용하여 농도를 조절한다(Hwang, 2018). 실제 작업조 건과 유사하게하기 위해 효소를 첨가한 산지별 옻칠과 테레핀유를 10:1의 비율로 하여 칠하였다. 옻칠의 Laccase와 부후균의 Laccase를 적용한 각각의 칠은 산지별로 구역을 나눈 목재시편에 초칠, 중칠, 상칠의 순서로 총 3 회 도포한 후 칠장에 넣어 건조하였다(Fig. 2).

\section{2. 연구방법}

2.2.1. 건조시간

우루시올 대비 Laccase의 함량을 조정하여 제작한 산지별 옻칠시편은 칠장(Drying room)을 이용하여 온도 $25 \pm 1{ }^{\circ} \mathrm{C}$, 습도 85-90\% 조건에서 건조를 실시하였다. 우루시올 대비 효소의 함량비율과 칠 횟수에 따른 산지별 옻칠의 시편별 건조양상을 30 분 간격으로 관찰하였으며, 옻칠의 건조가 완료되는 시간을 측정하였다. 또한 같은 방법으로 제작한 시편을 온도 $20 \pm 2$ ${ }^{\circ} \mathrm{C}$, 습도 55-60\%의 실내에 노출시켜 상온건조의 가능성을 확인하였다.

건조여부를 확인하는 시험방법은 'KS M 5000 도료 및 관련 원료의 시험방법’ 중 ‘시험방법 2511 , 도료의 건조 시간 시험방법 (바니시, 래커, 에나멜 및 수성 도료)'에 의해 지촉 건조와 경화 건조 상태를 확인하여 건조시간을 측정하였다.

\subsection{2. 색도 및 광택도}

색도와 광택도는 분광측색계(CR-400, KONICA MINOLTA)와 분광측색계(A-6800, BYK)를 사용하여 조건별 옻칠 표면을 3 회 반복 측정하였으며 색도 측정값은 $\mathrm{L}^{*}, \mathrm{a}^{*}, \mathrm{~b}^{*}$ 값으로, 광택도는 $\mathrm{G}$ 값으로 나타내었다.

생칠(A)의 $\mathrm{L}^{*}, \mathrm{a}^{*}, \mathrm{~b}^{*}$ 값을 기준으로 식 (1)을 이용하여 시편별 측정값을 $\mathrm{L}^{\prime *}, \mathrm{a}^{\prime *}, \mathrm{~b}^{\prime *}$ 에 대입해 색차값( $\left(\Delta \mathrm{E}^{*}\right)$ 을 구하였다 (Hidayat et al., 2017). 일반적으로 $\Delta \mathrm{E} 3$ 이내는 색상차이를 인식하지 못하고 $\Delta \mathrm{E}$ 6이내는 감각적으로 동일한 색상으로 판단한다. 


$$
\begin{aligned}
& \Delta E^{*}= \sqrt{\left(L^{*}-L^{\prime} *\right)^{2}+\left(a^{*}-a^{\prime}\right)^{2}+\left(b^{*}-b^{*}\right)^{2}} \\
& \mathrm{~L}^{*}: \text { Degree of lightness (white } 100 \sim 0 \text { dark) } \\
& \mathrm{a}^{*} \quad: \text { Degree of redness (red }+50 \sim-50 \text { green) } \\
& \mathrm{b}^{*} \quad: \text { Degree of yellowness (yellow }+50 \sim-50 \text { blue) }
\end{aligned}
$$

\subsection{3. 표면관찰}

효소 첨가에 따른 옻칠표면의 건조양상을 확인하고자 휴대용현미경(Lite plus AM313, DINO)을 이용하여 건조된 옻칠표면을 관찰하였다. 건조된 옻칠표면은 60 배로 확대하여 관찰하였으며, 건조된 옻칠시험편 중 중칠과 상칠의 표면을 촬영하였다.

\subsection{4. 단면관찰}

건조된 옻칠 시험편에서 상칠의 칠편을 채취하여 박편을 제작하였다. 슬라이드글라스 위에 박편을 올린 후 글리세린 수용액 $50 \%$ 떨어뜨리고 커버글라스를 덮어 프레파라트를 제작하였다. 제작된 프레파라트는 광학현미경(Eclipse Lv 100, Nikon, Japan)을 이용하여 도막의 단면을 관찰하였다(Kim et al., 2010).

\subsection{5. 밀착력}

건조된 옻칠의 밀착력을 확인하기 위하여 'KS M ISO 2409, 도료와 바니시-도료의 밀착성 시험방법'에 의하여 그 성능을 평가하였다. 건조된 옻칠시편에 메스를 사용하여 격자무늬로 가로 6줄, 세로 4줄을 잘라 간격이 $5 \mathrm{~mm}$ 인 30 개의 눈금을 만든다. 격자를 낸 시험편 위에 투명한 점착테이프를 밀착시킨 후 떼어내어 박리되는 면적을 계산하였다(Roh and Kim, 2008). 시험편 중 도막의 층위가 존재하는 중칠과 상칠을 대상으로 밀착력을 평가하였다.

\subsection{6. 적외선분광분석}

Laccase의 첨가에 따른 산지별 옻칠의 성분변화를 관찰하고자 적외선분광분석을 실시하였다. 적외선분광분석은 Cary620 Microscope(Agilent, USA) FT-IR장비를 사용하였으며, 유리판 위에 옻칠만을 건조시켜 제작한 시료를 대상으로 분석하였다 (Kim, 2016). 분석조건은 ATR모드로 설정하여 분해능 $4 \mathrm{~cm}^{-1}$, 측정범위 $400-4000 \mathrm{~cm}^{-1}$ 에서 32회 스캔하였다(Lee and Kim, 1990).

\subsection{7. 열분해 가스크로마토그래피 질량분석}

Laccase의 첨가에 따른 옻칠 성분의 변화를 확인하고자 열분해 가스크로마토그래피 질량분석을 실시하였다. 열분해장치 (Py-3030D, Frontier Lab, JPN)을 이용하여 전처리 없이 건조된 옻칠 시편을 주입구에 투입하여 분석하였다. 주입구 온도는 $250{ }^{\circ} \mathrm{C}$ 이며 열분해온도는 $600{ }^{\circ} \mathrm{C}$ 로 설정하였다.

가스크로마토그래피/질량분석기(6890A, Agilent, USA/5975C, Agilent, USA)를 사용하여 DB-5ms column(Agilent, USA) 으로 분석을 실시하였다. 오븐의 온도는 $40{ }^{\circ} \mathrm{C}$ 에서 5 분간 유지한 후 $300{ }^{\circ} \mathrm{C}$ 까지 분당 $20{ }^{\circ} \mathrm{C}$ 의 속도로 온도를 상승하도록 설정하였으며, $300{ }^{\circ} \mathrm{C}$ 에서 10 분간 유지하여 분석하였다. Split 모드로 이동상의 기체는 $\mathrm{He}$ 사용하여 $1.0 \mathrm{~mL} / \mathrm{min}$. 유속으로 실시하였다. 질량분석기의 Ion source는 EI 70eV이다(Choi and Kim, 2018).

\section{3. 결과 및 고찰}

\section{1. 건조시간}

옻칠의 Laccase와 부후균의 Laccase를 적용한 경우 국내산과 중국산 옻칠 모두 Laccase를 적용하지 않은 시험편 보다 건조시 간이 단축되었다. 또한 Laccase를 적용한 시험편 모두 건조 초기 60 분 안에 지촉건조가 이루어졌으며, Laccase의 함량비율이 높아질수록 건조속도가 향상하였다(Table 4).

옻칠의 Laccase를 적용한 결과, 우루시올 대비 Laccase의 함량비율이 5:1일 때 건조속도가 향상되면서 육안상 표면의 변화가 관찰되지 않는 것을 확인하였다. 따라서 우루시올 대비 Laccase 함량비율이 5:1일 때가 가장 안정적인 조건으로 판단하여 정제된 부후균의 Laccase를 같은 비율로 적용하여 건조하였다.

부후균 Laccase를 적용한 결과, 초칠의 경우 국내산 옻칠에서만 건조시간이 단축되고 중국산 옻칠은 생칠보다 오히려 건조속 
도가 느려지는 것이 관찰되었다. 중칠과 상칠의 경우는 산지의 구분 없이 옻칠의 Laccase를 적용한 시험편과 유사한 양상으로 건조속도가 향상하였다.

상온건조 실험결과, 산지와 칠 횟수에 따라 옻칠의 경화건조시간의 차이는 있지만 온도 $20 \pm 2{ }^{\circ} \mathrm{C}$, 습도 $55-60 \%$ 의 상온에서 도 경화건조가 이루어지는 것이 확인되었다(Table 3). 생칠 시편의 경우 낮은 습도조건에서는 칠이 건조되지 않는 것과 비교하여 Laccase를 첨가제로 적용함으로써 건조속도의 향상되는 것뿐만 아니라 높은 습도환경이 요구되는 옻칠의 건조조건을 개선할 수 있을 것으로 판단된다.

\section{2. 색도 및 광택도}

생칠인 시편 $\mathrm{A}$ 의 색도값을 기준으로 옻칠의 Laccase를 적용한 중칠 시편들의 $\Delta \mathrm{E}^{*}$ 값과 상칠 시편들의 $\Delta \mathrm{E}^{*}$ 값은 모두 3 이내로 색상차이를 인지하지 못하는 정도로 변화가 미미하였다(Table 5). $\Delta \mathrm{E}^{*}$ 값이 가장 크게 확인된 XL 시편의 $\Delta \mathrm{E}^{*}$ 값도 6 이내로 감각적으로 동일한 색상으로 판단되었으므로(Table 6), Laccase 첨가로 인한 옻칠의 색상변화는 크지 않은 것으로 판단하였다.

광택도는 중칠의 경우 옻칠의 Laccase와 부후균의 Laccase를 적용한 모든 시편의 광택도가 생칠보다 낮게 확인되었으며, Laccase의 함량비율이 높아질수록 광택도가 감소하였다. 이는 옻칠의 건조속도가 향상됨에 따라 산화반응이 급격하게 일어나면 서 옻칠 표면에 빛이 산란하게 되는 간섭요소가 나타난 것으로 추정된다.

\section{3. 표면 관찰}

건조된 옻칠시편의 표면을 관찰한 결과, 옻칠이 비교적 균일하게 도포되어 있었으며 칠하는 횟수가 올라갈수록 시편의 목재색 보다는 옻칠의 진한색이 관찰되었다.

옻칠의 Laccase를 적용한 국내산과 중국산 옻칠시편 모두 Laccase 함량비율이 높아질수록 $\mathrm{G}$ 와 $\mathrm{H}$ 처럼 표면에 미세한 갈라짐 이 확인되었으며(Table 7), 부후균의 Laccase를 적용한 시편은 칠하는 횟수가 더해짐에 따라 표면에 옻칠이 우는 것과 같은 주름이 관찰되었다(Table 8).

칠하는 횟수마다 칠도막의 두께가 30 40 $\mu \mathrm{m}$ 로 비교적 일정량의 칠이 도포되었으나 Laccase의 함량비율이 높아짐에 따라 상칠이 경화되는 과정에서 부후균의 Laccase를 첨가하였을 때 옻칠의 Laccase를 첨가한 것보다 상대적으로 건조시간이 더 소요되면서 미세한 갈라짐이나 주름등의 양상이 나타난 것으로 추정된다. 이에 대한 추가적인 연구가 필요할 것으로 판단된다.

\section{4. 단면 관찰}

옻칠과 부후균의 Laccase를 적용한 시편 모두 초칠의 경우 목재 내부로 스며든 형태와 그 위로 도막이 형성된 층이 확인되었 다. 국내산 옻칠의 도막의 두께는 초칠 약 $25 \mu \mathrm{m} \sim 45 \mu \mathrm{m}$, 중칠 약 $20 \mu \mathrm{m} \sim 40 \mu \mathrm{m}$, 상칠 약 $25 \mu \mathrm{m} \sim 45 \mu \mathrm{m}$ 이며, 중국산은 초칠, 중칠, 상칠 모두 약 $25 \mu \mathrm{m} \sim 45 \mu \mathrm{m}$ 로 평균 약 $40 \mu \mathrm{m}$ 로 관찰되었다. 칠을 더 한 횟수만큼 도막이 형성된 것으로 보아 Laccase의 효소를 적용한 시편 모두 경화건조가 잘 이루어 진 것으로 판단된다.

그러나 우루시올 대비 Laccase 함량비율이 높아질수록 Table 9의 국내산과 중국산 $\mathrm{E} \sim \mathrm{H}$ 에서 관찰되듯이 옻칠 표면층에서 미세한 갈라짐이 확인되었다. 이는 건조속도가 급속도로 향상하여 건조 초기에 옻칠 내에서 수축률의 차이가 발생함에 따라 도막형성과정에 영향을 미치는 것으로 추정된다.

\section{5. 밀착력}

옻칠과 부후균의 Laccase를 적용한 시편 모두 메스에 의한 미세한 박리 외에 칠편이 모두 밀착되어 있어 박리율 $0.5 \%$ 이내로 확인되었다(Table 10). 또한 Laccase 함량비율에 따른 옻칠의 밀착력의 변화는 관찰되지 않아 산지별 시험편의 경화건조 후 밀착력은 모두 안정적인 것으로 판단하였다.

\section{6. 적외선 분광분석}

국내산 옻칠과 중국산 옻칠의 스펙트럼의 피크가 서로 유사하게 관찰되었으며, 옻칠에서 관찰되는 특정 피크들이 모든 시편의 FT-IR 스펙트럼에서 관찰되었다(Park et al., 2017; Yeon et al., 2019).

$1500 \mathrm{~cm}^{-1}$ 이하의 지문영역을 확대하여 분석한 결과, Laccase의 첨가비율에 따라 C-O의 신축진동 피크가 나타나는 1270 $1190 \mathrm{~cm}^{-1}$ 영역에서 흡광도의 차이가 관찰되었다(Fig. 3). 5:1의 비율로 부후균의 Laccase를 적용한 경우 국내산과 중국산의 
스펙트럼 모두 같은 영역에서 흡광도의 차이가 나타났으며, 산치별 옻칠 간의 차이는 거의 관찰되지 않았다(Fig. 4).

이는 Laccase를 첨가량에 따라 산화반응의 정도가 달라지면서 이 영역에 해당하는 Alcohol이나 Phenol의 구조변화의 차이가 나타난 것으로 판단되며, FT-IR 스펙트럼 피크의 세기의 차이는 있으나 피크가 사라지지 않은 것으로 보아 물성에는 큰 영향은 미치지는 않는 것으로 사료된다.

\section{7. 열분해가스크로마토그래피 질량분석}

국내산 시편은 Styrene, Benzene, Propyl-, Benzealdehyde, Benzene, butyl- 등과 같은 Benzene계 화합물 및 Phenol,2-propyl등의 Phenol계 화합물이 관찰되었다. 이는 옻칠의 주성분인 우루시올이 산화반응에 의해 경화하면서 나타나는 성분들이며, 이와 함께 건조과정에서 발생하는 Biphenyl 형태의 이합체도 함께 확인되었다. 또한 알킬사슬고리에서 유래된 Undecane, Dodecane 등이 검출되었다.

중국산 시편은 Ethylbenzene, Benzene, 1,3-dimethyl-, Benzene, Propyl-, Benzene,1-methyl-4- propyl, 등과 같은 Benzene계 화합물 및 Phenol,2-methyl-, Phenol,4-ethyl- 등의 Phenol계 화합물이 관찰되었다. 또한 알킬사슬고리에서 유래된 Decane, Undecane, Dodecane, Tetradecane, Pentadecane 등의 성분들이 검출되었다.

Laccase 첨가에 따른 옻칠시편에서 검출된 성분들은 주성분인 우루시올이 Laccase의 활성에 의해 산화반응하여 경화건조되 는 과정에 확인되는 성분들이 주로 검출되었으며, 산지별 옻칠 간의 차이는 관찰되지 않았다. 또한 우루시올 대비 Laccase 함량비율이 5:1이 되게 Laccase를 첨가하여도 우루시올의 산화반응의 촉매역할을 하면서 옻칠의 물성에 영향을 줄 정도의 변화는 일어나지 않는 것으로 판단된다.

\section{4. 결 론}

옻칠과 백색부후균의 Laccase를 적용하여 옻칠의 건조속도를 향상시키기 위한 효소첨가제로써의 가능성을 확인하고자 하였 다. Laccase를 적용한 결과, 국내산 옻칠과 중국산 옻칠 모두 Laccase를 적용하지 않은 시험편 보다 Laccase를 첨가한 시험편의 건조시간이 단축되었다. 또한 Laccase를 적용한 시험편 모두 건조시작 60 분 안에 지촉건조가 이루어졌으며, Laccase의 함량비율 이 높아질수록 건조속도가 향상하였다.

또한 국내산 옻칠과 중국산 옻칠의 경화건조시간의 차이는 있지만 온도 $20 \pm 2{ }^{\circ} \mathrm{C}$, 습도 $55-60 \%$ 의 상온에서도 경화건조가 이루어지는 것이 확인되었다. 생칠 시편의 경우 낮은 습도조건에서는 옻칠이 건조되지 않는 것과 비교하여 Laccase를 첨가제로 적용함으로써 건조속도의 향상되는 것뿐만 아니라 높은 습도환경이 요구되는 옻칠의 건조조건을 개선할 수 있을 것으로 판단된다.

건조된 시험편의 도막분석 결과, 우루시올 대비 Laccase 함량비율이 5:1일 때 건조속도가 향상되면서 색차와 밀착력의 차이가 관찰되지 않고 도막이 안정적임을 확인하였다. Laccase를 적용한 경우 국내산과 중국산 옻칠 모두 광택도가 감소되는 양상이 관찰되었으나 이외 FT-IR과 Py-GC/MS의 분석결과, 물성에 영향을 미치는 정도의 성분변화는 나타나지 않아 첨가제로써의 적용이 가능할 것으로 판단된다. 또한 본 연구결과를 통해 칠기문화재 보존을 위한 옻칠 사용의 접근성을 높이며 원형보존의 진정성 있는 보존처리가 이루어 질 수 있을 것으로 기대한다. 